\title{
Settlement Area Type as a Factor in Electoral Behaviour in Slovenia
}

\author{
Jernej Tiran
}

Some political scientists believe that a new form of political cleavage has arisen in Slovenia over the past few years, which runs along the "urban" and "rural" axis. In this research, the relation between the settlement area type according to the level of urbanisation and the electoral results of the parliamentary elections from 1996 to 2008 has been observed. The research strategy was based on comparing the electoral results from their respective polls with an appropriate typification of settlements. Based on the analysis of variance (ANOVA), the calculation of the Eta squared coefficient and the analysis of parties' vote percentages and voter bases, the hypothesis may be safely confirmed, stating that there is a newly-founded political cleavage between the urban and the rural areas.

Key words: political geography, rural areas, urban areas, voters, Slovenia

\section{Tip naselja kao faktor biračke naklonosti u Sloveniji}

Neki politolozi smatraju da se posljednjih godina u Sloveniji pojavio novi oblik političke podijeljenosti - između ,urbanog” i ,ruralnog”. U ovom su istraživanju proučavani odnosi tipa naselja s obzirom na razinu urbanizacije i izbornih rezultata na parlamentarnim izborima od 1996. do 2008. godine. Istraživanje se temelji na usporedbi izbornih rezultata biračkih mjesta uz odgovarajuću tipizaciju naselja. Na temelju analize varijance (ANOVA), eta koeficijenta korelacije i analize biračkih tijela i rezultata stranaka, hipoteza o novostvorenoj podjeli između urbanih i ruralnih područja može se sa sigurnošću potvrditi.

Ključne riječi: politička geografija, ruralna područja, urbana područja, Slovenia 


\section{INTRODUCTION}

One of the main cleavages that Slovenia has had to deal with in the past has been a specific type of the left-right cleavage, based mainly on ideological issues such as the attitude towards the Catholic Church and the previous socialist regime. In 2008, the year of the $5^{\text {th }}$ democratic parliamentary elections after the independence in 1991, there were some assumptions that a new type of political division had taken place in Slovenia - the urban-rural cleavage (Pikalo, 2008; Lukšič, 2008). This assumption is somehow surprising; after the Second World War, strong modernisation of the rural areas, caused by an intensive de-agrarisation, industrialisation and urbanisation, diminished the differences between cities and villages, erasing the visible line between them (Ravbar, 1992; Klemenčič, 2002; Klemenčič, 2006). In addition, we are witnessing ever smaller differences between the programmes and paradigms of the Slovenian political parties after the 2000 elections, because a post-modernistic contemporary campaign demands a universal programme that does not make apparent distinctions between political options (Miheljak, 2004). The discussion about the urban-rural cleavage, which was most notable in 1988 with the formation of the Slovenian Peasant Union, has more or less died down in recent years, at least when examining the absence of this topic in political and academic discourse.

Nowadays, the aforementioned political scientists base their hypothesis on the rightwing parties' activities to mobilise voters mainly from the rural areas, largely on the basis of their specific lifestyle. After the recent elections, there was also a lot of discussion about the mobilisation of voters from Ljubljana - the capital city - since the turnout in its electoral districts was significantly higher compared to that in the 2004 elections, and because this is where the left-wing parties achieved an extremely high percentage of votes.

The increasing importance of the settlement area type as a factor in electoral behaviour in recent times has been noted by some foreign researchers, (Abrial et al., 2003; Honey and Barnett, 1990; McKee, 2008; Scheiner, 1999; Wasko and O'Neill, 2007), while the importance of the settlement area type as a factor in electoral behaviour in Slovenia, especially in the last decade, has not been sufficiently researched. The main purpose of this research was to inspect and observe if there is any correlation between the level of urbanisation and the electoral results, and if that strength of association really increased in the 2008 voting year. Moreover, there was the question of whether the hypothesis of the urban-rural cleavage could be verified on the basis of the electoral results.

\section{METHODOLOGY}

The classical approach - the analysis of the electoral results in the 88 electoral districts - proved unsuitable, as it was quite difficult to determine whether the urban-rural cleavage really existed in Slovenia, mostly because the majority of these districts are quite heterogeneous; they include urban, suburban as well as rural areas. This fact demanded a more detailed approach. In this research, the electoral data of the smallest spatial unit available - the polling station - was analysed. This decision was further supported by the fact that the electoral results on the polling station level had not yet been examined in Slovenia. The electoral results were obtained from the Republic Electoral Commission. The results of four consecutive parliamentary elections - 1996, 2000, 2004 and 2008 - were analysed; 
the detailed results of the previous elections $(1990,1992)$ were not available. The spatial data of the polling stations from the Register of Spatial Units run by the Surveying and Mapping Authority of the Republic of Slovenia, which correspond to the state as it was on the day of each individual election, was also obtained.

To establish the strength of association between the settlement area type and the electoral results, it was first necessary to determine the type of each settlement according to the level of urbanisation. For this reason, an appropriate typification of settlements was necessary. A typification made by Dejan Cigale in 2005, which is based on certain pre-determined socio-geographical, physiognomic, structural and functional criteria (population density, migration balance, percentage of single-family homes in the mutual housing fund, daily worker migrations, etc ...) was applied. Here, the settlements are divided into 6 groups according to the level of urbanisation ${ }^{1}$.

The typification of the polling stations was carried out using the ArcGis 9.2 programme and its tool Identity, which allowed the overlapping of the cartographic layer of the typification with the polling station level. This process had to be carried out for each parliamentary election, as the number of polling stations varied from one election to another. The typification process revealed that the polling station boundaries mostly correspond with the boundaries of the settlements; the cities and bigger settlements are generally divided into several polling stations, while the predominantly rural polling stations usually consist of two, three or more settlements. As Fig.1 demonstrates, it was not possible to determine the type of some polling stations, because they consisted of more settlements with different levels of urbanisation. These polling stations were assigned a type only in the case when a certain type of settlement represented at least $75 \%$ of the inhabitants of the total number of voters assigned to a specific polling station. Here the data from the 2002 Census Survey of Population, Households and Homes was used.

The percentage of polling stations included in the analysis increased with this method from $74 \%$ to $84 \%$ (data for the 2008 parliamentary elections). A polling station typification on the basis of a simplified typification, where the settlements are divided into 3 types instead of 6: cities, urbanised settlements (joined suburbanised, urbanised and distinctly urbanised rural settlements) and rural settlements (joined urbanised rural and rural settlements) was also carried out. Using this kind of typification does entail a certain loss of information, but it also allowed the inclusion of more polling stations in the analysis (up to $90 \%$ in the 2008 elections).

The degree of association between the electoral results and the level of urbanisation was determined using selected quantitative methods. Since there are more than two independent variables ( 6 or 3 types of polling stations according to the level of urbanisation) and one dependent variable (the percentage of votes for each political party), the assumption that the correlation between both variables is statistically significant with the F-test using the one-way variance analysis (ANOVA) in the SPSS programme was tested. In other words, the test of the null hypothesis that there are no statistically significant differences between the electoral results of all four analysed elections was done. To perform the variance analysis, the following conditions must usually be met: normality, homoscedascity and equal sample size. The first two conditions could not be met even after transforming the 


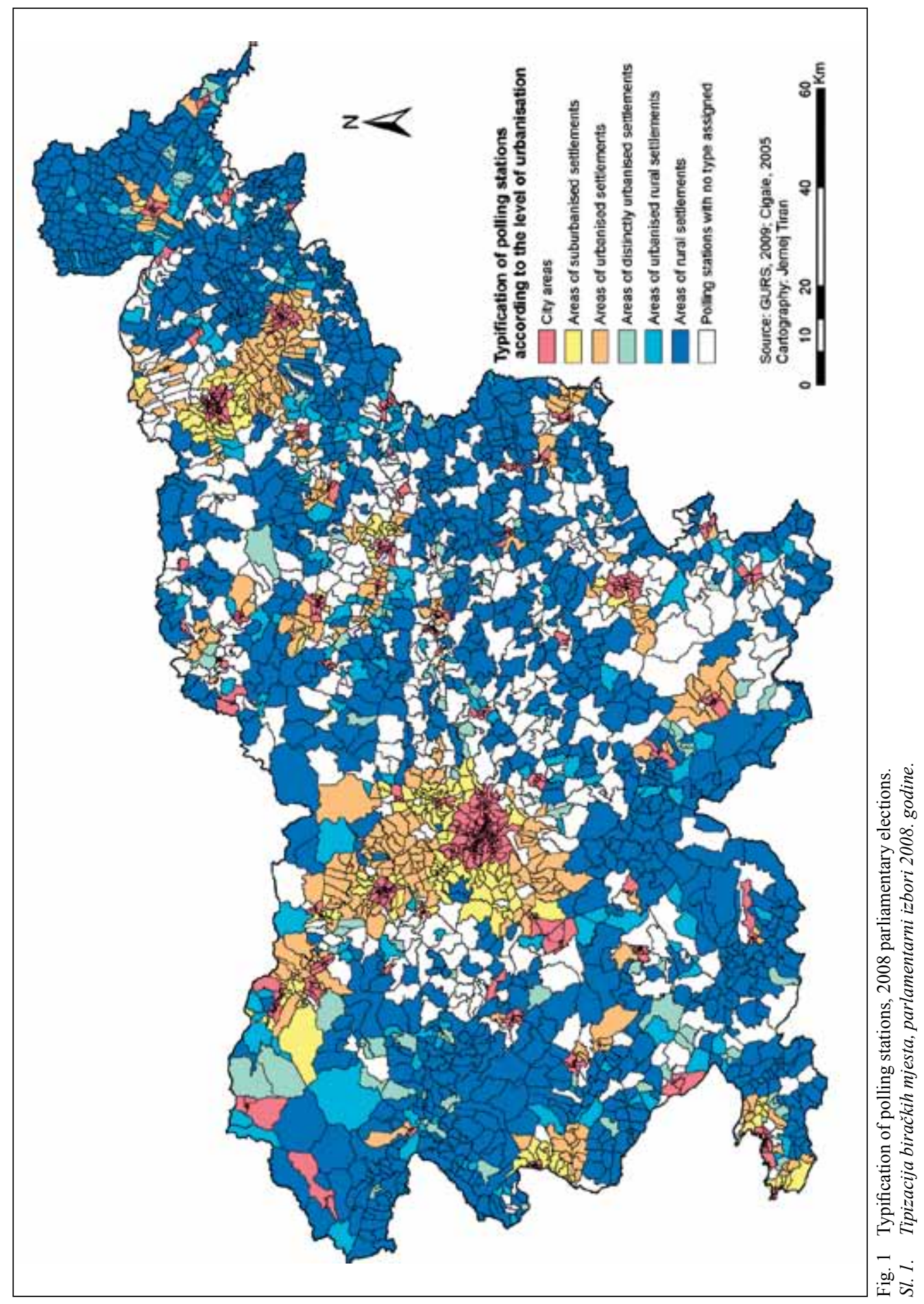




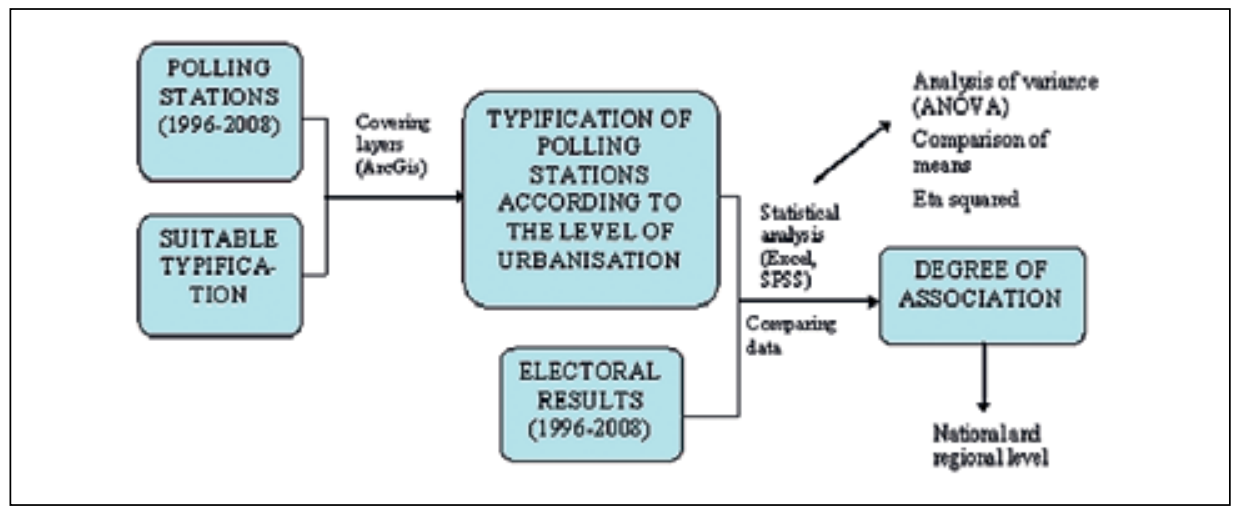

Fig. 2 Methodological approach.

Sl. 2. Metodološki pristup.

variables, so to avoid incorrect results, additional specific F-tests were performed, such as the Brown-Forsythe, Welch and Kruskal-Wallis. To determine the statistical characteristics of the differences between individual group averages, the more precise post-hoc testing (Tamhane's T2 test) was also executed.

The results of the general F-test, expressed by Snedecor's F-distribution, could be used for comparison between individual elections, but could not be properly interpreted due to the absence of a measuring scale. For this reason, the calculation of the Eta squared coefficient in the SPSS programme was made. The Eta squared coefficient illustrates the variance percentage of the dependent variable, explained by the differences between groups. By comparing its values in the period between 1996 and 2008, the elections that showed the strongest connection between the level of urbanisation and the electoral results were established, and the possible trend was determined.

A simple calculation of the vote percentages for each party according to the settlement type using the Excel programme was done. The parties had varied success in the elections and, therefore, to enable a more accurate comparison and to determine its voter base, the vote percentages in each settlement type that contributed to the overall number was also calculated.

\section{THE CORRELATION BETWEEN THE LEVEL OF URBANISATION AND ELECTORAL RESULTS IN SLOVENIA}

The variance analysis (F-test, Welch, Brown-Forsythe, Kruskal-Wallis) showed that the differences between the electoral results in individual settlement types are statistically significant, allowing for a $5 \%$ level of significance for most of the political parties in all four studied parliamentary elections, using the simplified as well as the original typification. The findings confirm the assumption that the settlement area type is an important factor in forming the electoral results in Slovenia.

Post-hoc testing showed that the differences between the group averages were specific only for some pairs of settlement area types. It was established that the typification in 6 
groups is not "optimal". None of the parties in the studied period showed that the differences in votes were statistically significant in all pairs of settlement area types. Displaying the results according to 3 settlement area types (cities, areas of urbanised settlements, areas of rural settlements) proved to be more effective, despite a certain loss of information, and it is therefore used in the remainder of the article.

When executing certain tests, it was found that there are only two major parties in Slovenia that do not show statistically significant differences in the electoral results in the studied period. These are the DeSUS (Democratic Party of Pensioners of Slovenia; elections in 1996, 2000 and 2008) and the LDS (Liberal Democratic Party; 2008 elections). According to these tests and the electoral results in Tab.1, the DeSUS may be signified as a political party that speaks mostly to a specific, older part of the population and thus acts away from the urban-rural axis. The loss of the previously recognisable profile of the once- leading LDS party as predominantly urban can be ascribed to its recent program and staff overhaul after their failure in the parliamentary elections in 2004, as well as to the concentration of urban votes to the party's recent coalition partner, the SD (Social Democrats). The SD achieved above average electoral results in all four studied elections in the cities in relation to the other settlement area types and can from this aspect be classified - together with the NSi (New Slovenia Christian People's Party) and the SLS (Slovenian People's Party), which constantly reached a higher voter percentage in the rural areas - in a group of political parties, whose electoral results are seen as "stable" from this perspective, together with those of the DeSUS. The reverse holds for the SNS (Slovenian National Party) and the SDS (Slovenian Democratic Party), which was the leading party in the 2004-2008 mandate and is today the biggest opposition party. With a similar total percentage of votes, the SDS improved its electoral results in the rural areas in the 2008 elections, while the results deteriorated significantly in the cities in comparison to previous elections. The SNS has been following this kind of trend for some time and it peaked in the last election, when it reached significantly higher results in the rural areas. This is most likely a consequence of the cleft within the party and the emergence of the new political party, the LIPA, which took the majority of the city vote of the two parties. The 2008 electoral results of some political parties (the LDS, SDS, SNS) may lead us to assume that there have been some changes in the Slovenian political scene on the urbanrural axis in comparison to previous elections.

To determine whether the differences in electoral results between the cities and rural areas have increased, the relation between the level of urbanisation and the left/right wing division was also analysed. Based on public opinion polls (Toš, 1999, 2004, 2007, 2008) and programme similarities ${ }^{2}$, the political parties were divided into two wings: the left (the DeSUS, SD, LDS, ZARES) and the right (SLS, SKD/NSi, SDS). The parties, which could not be classified on one or the other side according to these requirements, were joined together in the category "other". 
Tab. 1 Electoral results of the major political parties 1996 - 2008, according to the settlement area type, vote percentages $(\%)$.

Tab. 1. Izborni rezultati glavnih političkih stranaka 1996.-2008. prema tipu naselja, postoci glasova (\%).

\begin{tabular}{|l|r|r|r|r|r|r|r|r|r|r|r|r|}
\hline & \multicolumn{4}{|c|}{1996} & \multicolumn{3}{|c|}{2000} & \multicolumn{3}{c|}{2004} & \multicolumn{3}{c|}{2008} \\
\hline & cities & urb. & rural & cities & urb. & rural & cities & urb. & rural & cities & urb. & rural \\
\hline DeSUS & 4.6 & 4.8 & 4.3 & 4.6 & 5.2 & 5.6 & 3.9 & 3.8 & 4.2 & 7.3 & 7.4 & 7.6 \\
\hline LDS & 31.4 & 25.9 & 22.3 & 41.9 & 34.6 & 29.8 & 27.7 & 21.1 & 16.9 & 5.3 & 5.0 & 5.1 \\
\hline SLS & 13.5 & 19.9 & 28.5 & 4.8 & 9.4 & 17.2 & 3.1 & 6.9 & 12.4 & 2.8 & 4.9 & 9.2 \\
\hline SD & 13.3 & 8.1 & 5.3 & 14.8 & 11.3 & 8.1 & 13.0 & 8.9 & 6.8 & 38.3 & 28.4 & 20.7 \\
\hline SDS & 13.4 & 16.1 & 14.6 & 13.7 & 17.6 & 18.1 & 26.3 & 31.6 & 31.2 & 23.2 & 31.8 & 36.3 \\
\hline SKD/NSi & 6.9 & 10.0 & 13.6 & 6.8 & 9.0 & 10.5 & 7.0 & 9.3 & 11.9 & 2.2 & 3.3 & 4.7 \\
\hline SNS & 4.0 & 3.3 & 2.2 & 5.2 & 4.4 & 3.3 & 6.7 & 6.4 & 5.4 & 4.4 & 5.8 & 6.8 \\
\hline ZARES & $/$ & $/$ & $/$ & $/$ & $/$ & $/$ & $/$ & $/$ & $/$ & 11.8 & 9.1 & 6.0 \\
\hline
\end{tabular}

The structure of the voter bodies of both wings according to the settlement area type shows that the voter body of the left wing in the studied period consists of an above average number of voters from cities and a smaller, yet important percentage of voters from urbanised and rural settlements (Fig. 3). The structure of the right wing's voter body is different - the percentages of votes from cities and rural areas seem to be quite similar (Fig. 4).

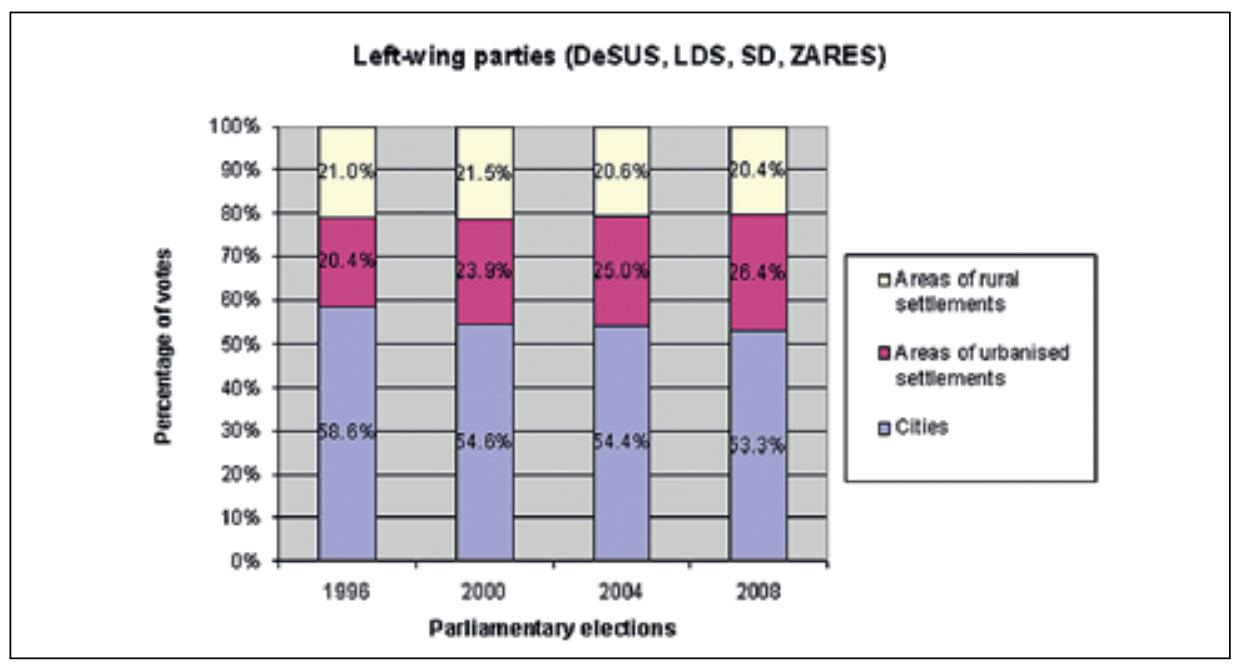

Fig. 3 Structure of the left wing's voter body according to the settlement area type, 1996-2008 parliamentary elections.

Sl. 3. Struktura biračkog tijela ljevice prema tipu naselja, parlamentarni izbori 1996.-2008. godine. 


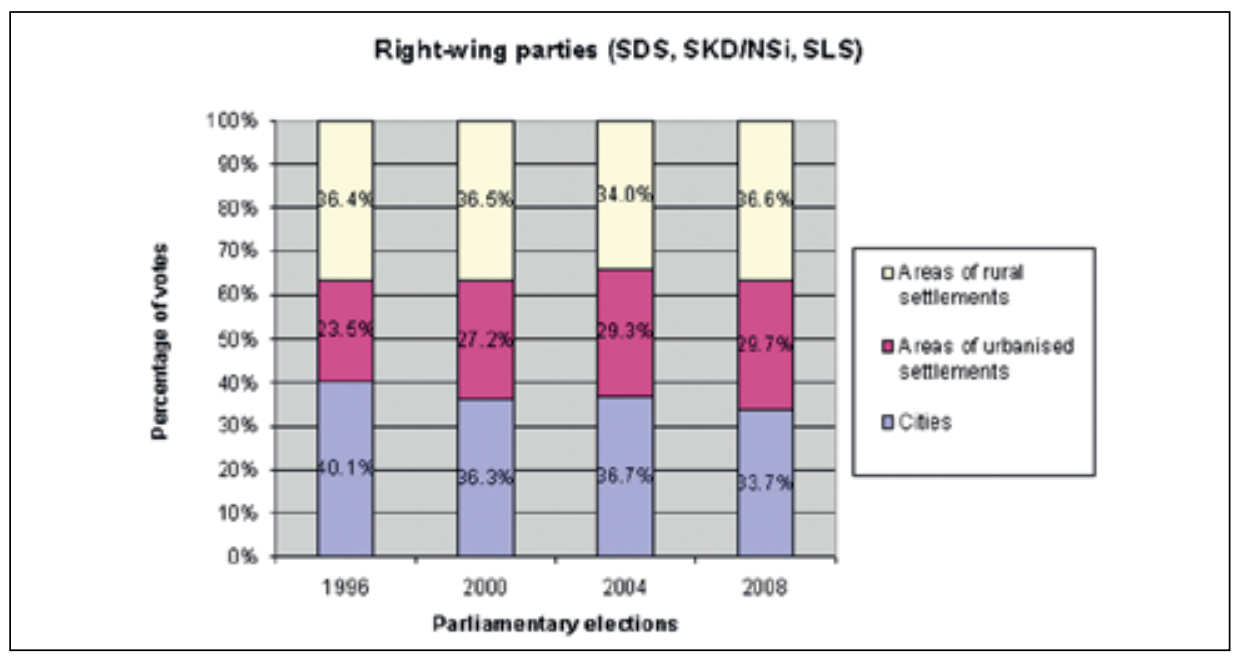

Fig. 4 Structure of the right wing's voter body according to the settlement area type, 1996-2008 parliamentary elections.

Sl. 4. Struktura biračkog tijela desnice prema tipu naselja, parlamentarni izbori 1996.-2008. godine.

Both figures clearly demonstrate that the voter percentages from areas of urbanised settlements are constantly increasing, whereas the share of voters from cities is constantly decreasing. This fact correlates to the modern settlement patterns in Slovenia, where the areas of urbanised settlements have been noticing above-average population growth since the 1960s, at first because of the decrease of the number of inhabitants in rural areas, and from the late 1980s onwards due mainly to the decreasing number of inhabitants in the cities (Ravbar, 1992; Rebernik, 2008). The biggest change within both wing voter bodies occurred in the 2008 elections, when the right wing noticed a visible drop in the number of voters from cities and inversely, a noticeable increase of voters from rural areas, which was, at $36.6 \%$, the highest in the studied period.

The explanatory power, that is, the strength of association between the electoral results and the level of urbanisation, is best demonstrated by the Eta squared coefficient. Tab. 2 shows how its explanatory power was the strongest in the 2008 elections and how it visibly increased in comparison with past elections; this factor explains the high 38 and $34 \%$ variance of the left and right wing's electoral results, respectively, in 2008.

Tab. 2 Eta square coefficient in the elections, 1996 - 2008, according to party groups.

Tab. 2. Eta koeficijenti korelacije na izborima 1996.-2008. prema stranačkim grupacijama

\begin{tabular}{|l|c|c|c|c|}
\hline & 1996 & 2000 & 2004 & 2008 \\
\hline LEFT & 0.24 & 0.21 & 0.26 & 0.38 \\
\hline RIGHT & 0.29 & 0.23 & 0.23 & 0.34 \\
\hline OTHER & 0.10 & 0.06 & 0.01 & 0.02 \\
\hline
\end{tabular}


The increased explanatory power of the level of urbanisation in the 2008 elections may also be observed from the map (Fig. 5). It is visible that there is a strong spatial polarisation present on the Slovenian political scene. The colours blue and red dominate the map and they represent a strong supremacy of one or the other wing. It is also apparent that the left wing parties were noticeably more successful in all the bigger cities than the right wing parties (Ljubljana, Maribor, Celje, Kranj, Koper, Novo mesto ...), while the right wing parties - despite their defeat in the most recent elections - still "rule" the vast rural areas (Suha Krajina, Škofja Loka hills, Solčava region and large areas in eastern Slovenia). But the level of urbanisation is not an important factor only on the state level but on the regional level as well, although certain regional differences do appear. Aside from the Pomurska statistical region, the explanatory power of this factor increased in the 2008 election in all the statistical regions. The level of urbanisation had the highest explanatory power in the Osrednjeslovenska statistical region, where the classification of the polling stations according to their level of urbanisation in the 2008 election could be explained by a staggering $62 \%$ variance in electoral results for the left wing, and $59 \%$ for the right wing. An above average percentage of variance could also be noticed in the Podravska, Gorenjska and Savinjska statistical regions while in the other regions, especially in the Pomurska and Koroška statistical regions the explanatory power of this factor was lower. The reasons for this are most likely to be the lack of really urbanised centres, prevailing regional identity that blurs the boundaries between the "urban" and the "rural" and the stronger influence of individual candidates, well-known in the wider local environment.

Tab. 3 The correlation between the electoral results and the settlement area type in the statistical regions, demonstrated by the Eta squared coefficient, 2008 elections.

Tab. 3. Korelacija između izbornih rezultata i tipa naselja u statističkim regijama prikazana eta koeficijentom, izbori 2008. godine.

\begin{tabular}{|c|c|c|c|}
\hline $\begin{array}{c}\text { Rank/ } \\
\text { Map marking }\end{array}$ & $\begin{array}{c}\text { Statistical } \\
\text { region }\end{array}$ & $\begin{array}{c}\text { Eta } \\
\text { squared } \\
\text { (left) }\end{array}$ & $\begin{array}{c}\text { Eta } \\
\text { squared } \\
\text { (right) }\end{array}$ \\
\hline 1 & Osrednjeslovenska & 0.62 & 0.59 \\
\hline 2 & Podravska & 0.45 & 0.45 \\
\hline 3 & Gorenjska & 0.45 & 0.43 \\
\hline 4 & Spodnjeposavska & 0.42 & 0.36 \\
\hline 5 & Savinjska & 0.40 & 0.37 \\
\hline 6 & Zasavska & 0.19 & 0.43 \\
\hline 7 & Obalno-kraška & 0.35 & 0.22 \\
\hline 8 & Notranjsko-kraška & 0.32 & 0.24 \\
\hline 9 & Jugovzhodna Slovenija & 0.28 & 0.25 \\
\hline 10 & Goriška & 0.28 & 0.24 \\
\hline 11 & Koroška & 0.21 & 0.12 \\
\hline 12 & Pomurska & 0.16 & 0.10 \\
\hline
\end{tabular}




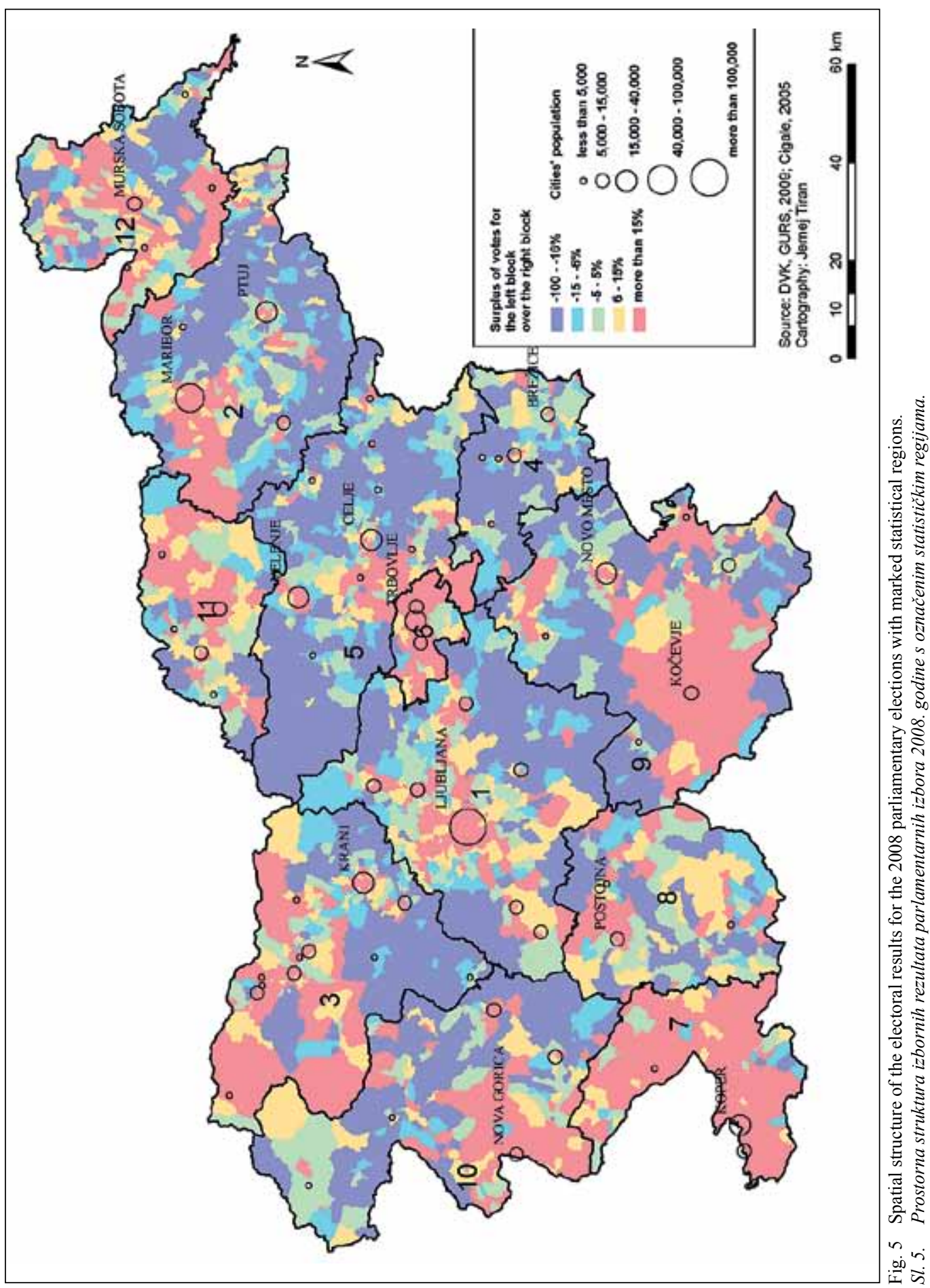




\section{CONCLUSION}

The implemented methodological approach of analysis on the level of the smallest spatial unit and the use of different statistical methods allowed for a very detailed and precise analysis of the electoral results and proved the hypothesis about the emergence of a new level of political conflict in Slovenia. The results of the variance analysis, the altered structure of the voter bodies of the political parties, the left and right wing and especially the increased explanatory power of the level of urbanisation in the 2008 election, demonstrated with the Eta squared coefficient, show that, despite the economical, spatial and population density development that constantly trends towards decreasing the differences between the urban and the rural areas, the political cleavage between the two has increased once again. However, this time it has not realised itself with the emergence of a new political party as happened in 1988, but is recognisable rather in the form of a more distinct spatial structure of the electoral results.

One may assume that the urban-rural cleavage in Slovenia is maintained largely by the differences in lifestyles and patterns that stem from the different identities of city and rural areas. The rural and the urban milieu, in addition to the differences in education, religiousness, values system, occupation, structure and socio-economic status, each possess their own certain "cultural capital". In Slovenia, a relation exists between cultural taste and political preferences (Luthar, 1993). At the same time, it is the cultural cleft that is one of the most defining factors in the Slovenian political situation (Vehovar, 1996). One may assume from such facts that lifestyle-based social cleavages are politically relevant in Slovenia. However, one must not forget the parties' own involvement and their activities and election campaigns in specific areas. This research has proved without doubt the presence of the urban-rural cleavage, while the question about what has caused this political polarisation, despite some indications, remains to be answered.

\section{NOTES}

1 Here, urbanisation is meant as the process of functional, social, economic and physiognomic transformation of rural areas in the way of decreasing the differences between the urban and the rural (Vresk, 2002, 17).

2 The ZARES party, which was not founded until 2007, was not included in these polls; therefore, its classification was determined by its own definition and political affiliations with other parties.

\section{REFERENCES}

Abrial, S., Cautres, B., Mandran, N., 2003: France: Turnout and abstention at multi-level elections, http://www. ucd.ie/dempart/workingpapers/france.pdf (22.11.2009.)

Census survey of the population, households and homes, 2002: Population by settlements, Statistical Office of the Republic of Slovenia, http://www.stat.si/popis2002/si/ (12.06.2009.)

Cigale, D. 2005: Posodobitev Ravbarjeve tipizacije naselij z vidika stopnje urbaniziranosti na podlagi RPE (2002), in: Krevs, M., 2005 (project holder): Ocena ponudbe in povpraševanja po zemljiščih za gradnjo na nivoju regije in države - priprava vhodnih podatkov in izvedba ankete : 1. phasic report, Faculty of Arts, Department of Geography, Ljubljana (database). 
Honey, R., Barnett, J. R., 1990: Volatile stability: New Zealand's 1987 general election, in: Developments in Electoral Geography (ed. Johnston, R. J., Shelley, F. M., Taylor, P. J.), Routledge, London, 86-99.

Klemenčič, M. M., 2006: Teoretski pogled na razvojne strukture slovenskega podeželja, Dela, 25, 159-170.

Klemenčič, V., 2002: Procesi deagrarizacije in urbanizacije slovenskega podeželja, Dela, 17, 7-21.

Lukšič, I., 2008: Pri upiranju skušnjavam je ključna kontrapomoč (interviewed by Stepišnik, M.), http://www. vecer.com/vecer2007/default.asp?kaj=3\&id=2008092605364565 (20.01.2009.)

Luthar, B., 1993: Pledoaje za raziskovanje politične izbire kot stilistične izbire, in: Volitve in politika po slovensko (ed. Adam, F.), Znanstveno in publicistično središče, Ljubljana, 113-138.

McKee, S., 2008: Rural Voters and the Polarization of American Presidential Elections, Political Science \& Politics 41 (1), 101-108.

Miheljak, V., 2004: Pogled v volilno ali Pandorino skrinjico?, http://www.dnevnik.si/tiskane_izdaje/dnevnik/94175 (15.09.2009.)

Pikalo, J., 2008: Ključ je v provinci, Mag, 14, (09.04.2008), 47

Ravbar, M., 1992: Suburbanizacija v Sloveniji: odnosi, strukture in težnje v njenem razvoju: doctor thesis, Faculty of Arts, Department of Geography, Ljubljana.

Rebernik, D., 2008: Urbana geografija : geografske značilnosti mest in urbanizacije v svetu, Scientific \& Research Institute of the Faculty of Arts, Ljubljana.

Republic Electoral Commission, 2009: Electoral results of the 1996, 2000, 2004 and 2008 parliamentary elections, voting polls (internal material).

Scheiner, E., 1999: Urban outfitters: city-based strategies and success in post-war Japanese politics, Electoral studies 18 (2). http://www.sciencedirect.com (16.06.2009.)

Surveying and Mapping Authority of the Republic of Slovenia, 2009: Polling stations and Electoral districts, 1.12.1996, 1.12.2000, 1.12.2004 in 1.12.2008 (digital data).

Toš, N., 1999: Vrednote v prehodu II. Slovensko javno mnenje 1990-1998, IDV - CJMMK, Ljubljana.

Toš, N., 2004: Vrednote v prehodu III. Slovensko javno mnenje 1999-2004, Faculty of Social Sciences, Ljubljana

Toš, N., 2007: Slovensko javno mnenje 2006: Poročila - 4. poročilo. Odnos do politike, političnih strank in politikov, http://www.cjm.si/sites/cjm.si/files/file/e-dokumenti/odnos_do_politike_politicnih_strank_in_politikov.pdf (12.09.2009.)

Toš, N., 2008: Vrednote v prehodu IV. Slovensko javno mnenje 2004-2008, Faculty of Social Sciences, IDV CJJMK, Ljubljana.

Vehovar, U., 1996: Družbeni razcepi in politične stranke na Slovenskem : master thesis, Faculty of Social Sciences, Ljubljana.

Vresk, M., 2002: Grad i urbanizacija : osnove urbane geografije (5. dopunjeno izd.), Školska knjiga, Zagreb.

Wasko, K., O’Neill, B., 2007: The Urban/Suburban/Rural Cleavage in Canadian Political Opinion, http://www. cpsa-acsp.ca/papers-2007/wasko-oneill.pdf(16.9.2009.)

Received (Primljeno): 2010 - 12 - 31

Accepted (Prihvaćeno): 2011 - 03 - 14

\author{
Jernej Tiran, \\ Department of Geography \\ Faculty of Arts \\ University of Ljubljana \\ SI-1000 Ljubljana, Aškerčeva 2 \\ nejc.tiran@gmail.com
}

